\title{
BANKRUPtCy PlanNing Is Not MATERIAL?
}

\author{
DALE A. Oesterle*
}

Federal securities laws prohibit managers from making "material" misstatements and omissions of fact to investors in their companies. ${ }^{1}$ The term material connotes a level of significance, importance or weight that justifies investor attention and reliance. ${ }^{2}$ The Supreme Court supplements the standard with a declaration that a material fact does not have to change an investor's vote or a trade ${ }^{3}$ and an anticipated event does not have to be probable to be material if it is of major importance. ${ }^{4}$ I have chronicled elsewhere the problems federal courts have with the over-breadth of the definition, ${ }^{5}$ but a series of three recent cases on bankruptcy planning are the breach in the levee.

It almost goes without saying that all investors, reasonable or otherwise, will be hugely interested if the management of a company in which they hold stock or bonds is contemplating filing for bankruptcy. On the filing, stocks will lose most of their value and debt goes into default. There is nothing more significant to an investor than this. Yet, amazingly, in three federal court cases, two of which are fairly recent, a management's discussions of bankruptcy are held, in essence, ${ }^{6}$ not to be material to

\footnotetext{
${ }^{*}$ J. Gilbert Reese Chair in Contract Law, The Ohio State University Moritz College of Law.

The fraud prohibitions are sprinkled throughout the statutes and laws. The best known is in Rule 10b-5. See, e.g., 17 C.F.R. $\S 240.10 b-5$ (2013).

${ }_{2}$ Rule 405 under the Securities Exchange Act of 1933 and $12 \mathrm{~b}-2$ under the Securities Exchange Act of 1934, for example, defines material as "those matters to which there is a substantial likelihood that a reasonable investor would attach importance." See, e.g., id. $\S \S 230.405,240.12 b-20$.

${ }^{3}$ TSC Indus. Inc. v. Northway Inc., 426 U.S. 438, 449 (1976) (explaining that a fact is material if it "would have assumed actual significance in the deliberations of the reasonable [investor]" or it "would have been viewed by the reasonable investor as having significantly altered the 'total mix' of information made available"); $i d$. at 449 (explaining that materiality "does not require proof that [accurate] disclosure ... would have caused the reasonable investor to change his vote"); see Basic Inc. v. Levinson, 485 U.S. 224, 232 (1988) (dealing with allegations of a misleading proxy statement). A subsequent opinion applied the language to all corporate disclosures affecting trading in the company's securities.

${ }^{4}$ Id. at 236 (adopting the test of Judge Friendly in SEC v. Tex. Gulf Sulfur Co., 401 F.2d 833,849 (2d Cir. 1968) (the necessary probability of an event of materiality slides backwards in light of its magnitude)).

5 Dale A. Oesterle, The Overused and Under-Defined Notion of "Material" in Securities Law, 14 U. PA. J. BUS. L. 167 (2011).

${ }^{6}$ There are judicial tricks that obscure the finding, noted in the discussion infra.
} 
investors. ${ }^{7}$ And equally astonishingly, the cases have been greeted by the securities bar with barely a ripple of discontent. ${ }^{8}$ How can this be?

The cases offer undeniable evidence of the basic proposition that materiality is a highly qualified term and that these qualifications have yet to be defined or, for that matter, even recognized.

\section{THE CASES}

\section{A. In re Tower Automotive Securities Litigation}

Tower Automotive Inc., a supplier of automotive parts, filed for bankruptcy protection on February 2, 2005..$^{9}$ Investors who had purchased Tower securities in a five-year period previous to the bankruptcy filing sued as a class, claiming various violations of Rule $10 \mathrm{~b}-5$. One of their claims was based on Tower's failure to disclose active bankruptcy planning three months prior to the filing. The complaint charged that, based on the CEO's deposition testimony, the company was working on contingency plans for a bankruptcy filing in October of 2004. Moreover, the complaint alleged that Tower's public statements from October to February were materially misleading because the statements did not mention the bankruptcy planning. In the statements, Tower indicated that it was "pursuing options for easing the company's liquidity problems, including pursuing (and later obtaining) an accounts receivable securitization facility and deferring a dividend payment." 10

The District Court dismissed the claim on two grounds. As is often seen in materiality cases, the logic is curious to the point of comedy because the real reasons for the holding are in the background, unstated. First, the court held that "[b]ecause Tower disclosed its intensive efforts to ameliorate the company's liquidity problem, the lack of disclosure regarding its bankruptcy planning did not transform its disclosure during this period into misrepresentations," should not have surprised investors given the company's known efforts to marshal cash. But, as any savvy businessperson will tell you, a company's efforts to marshal cash are a far cry from planning for an imminent bankruptcy filing. Despite these inconsistencies, judges in the Southern

\footnotetext{
${ }^{7}$ There were some early cases that did find bankruptcy plans to be material. See In re McLeodUSA Inc., No. C02-001-MWB, 2004 WL 1070570 (N.D. Iowa Mar. 31, 2004); Salkind v. Wang, No. 93-10912-WGY, 1995 WL 170122 (D. Mass. Mar. $30,1995)$.

${ }^{8}$ See, e.g., Richard J. Corbi, Nondisclosure of Planned Corporate Bankruptcy Does Not Violate Federal Securities Law, AM. BANKR. INST. J., July/Aug. 2009.

${ }_{10}$ The facts are from In re Tower Auto., 483 F. Supp. 2 d 327 (S.D.N.Y. 2007).

${ }^{10} \mathrm{Id}$. at 348 .

"Id. (citing Time Warner Inc., 9 F.3d 259, 267 (2d Cir. 1993)).
} 
District of New York are known for their business acumen. Moreover, the court, in a motion to dismiss must view all pleaded facts in the light most favorable to the plaintiffs.

Second, the court, planting the seed for future cases as we will see below, held that the claim did not adequately plead the element of scienter:

No multi-billion dollar company would file for bankruptcy without first engaging in internal deliberations regarding its course of action, and Tower was apparently no exception to this rule. However, "in the absence of any factual allegations from which one can infer that defendants had actually settled upon the details' of the bankruptcy plan in advance of the filing, Plaintiffs' allegations fail to evince any hint of fraudulent intent. ${ }^{12}$

Management's disclosures are not fraudulent if management knows of an imminent bankruptcy filing but does not know of its "settled . . details." Most bankruptcy plans, other than pre-packaged bankruptcies, evolve significantly after the filing, as management, if still in control as a debtor in possession, puts a plan of reorganization before the creditor committees. Nothing much is settled on filing. Why is a plan to file within a short time period not sufficient detail? A plan to merge, without settled details, is sufficiently material in Basic. ${ }^{13}$

The case of Beleson v. Schwartz provides some answers. ${ }^{14}$ Loral Space \& Communications, Ltd. was in severe financial distress in early $2003 .{ }^{15}$ The company hired an investment bank, Greenhill \& Co., to find possible merger partners. ${ }^{16}$ Harvey Miller, a partner at Weil, Gotshal \& Manges, LLP and one of the country's foremost bankruptcy specialists, was on the Greenhill advising team. ${ }^{17}$ A serious buyer emerged, Intelsat Ltd., who demanded in May of 2003 that Loral file a prepackaged bankruptcy to clear title to its satellites before any asset transfer. ${ }^{18}$ On May 30th, Loral and Intelsat agreed that the Intelsat sale, if finalized, would be completed in bankruptcy. ${ }^{19}$ Loral hired Weil, Gotshal \& Manges as bankruptcy counsel and continued to look for alternatives. ${ }^{20}$ On July 15th, Loral and Intelsat

\footnotetext{
${ }_{12}^{12}$ Id. (citing Fant v. Perelman, 1999 WL 199078, at*15 (S.D.N.Y. Apr. 9, 1999)).

${ }_{13}^{13}$ See generally Basic Inc. v. Levinson, 485 U.S. 224 (1988).

${ }_{114}^{14} 419$ Fed. App'x. 38 (2d Cir. 2011).

${ }_{15}^{15}$ Beleson v. Schwartz, 599 F. Supp. 2d 519, 521 (S.D.N.Y. 2009).

${ }^{16} \mathrm{Id}$.

${ }^{17} I d$.

${ }^{18} \mathrm{Id}$.

${ }^{19} \mathrm{Id}$.

${ }^{20} \mathrm{Id}$.
} 
signed an asset purchase agreement and Loral filed immediately for Chapter 11 bankruptcy. ${ }^{21}$

The Plaintiffs, those who had purchased securities from June 30th through July 15th filed a class action against the Loral CEO alleging Rule $10 \mathrm{~b}-5$ violations. ${ }^{22}$ The plaintiffs alleged four statements made during the period that were materially misleading in light of the bankruptcy plans. ${ }^{23}$ Three of the four statements were positive accounts of major Loral business transactions: a settlement with a major creditor, an accelerated collection of a large accounts receivable, and a major contract to build space station replacement batteries. ${ }^{24}$ One statement was from the CEO stating that Loran was "on plan" to have $\$ 65$ million in cash by year's end. ${ }^{25}$ All of the statements were technically true; they just did not mention the impending bankruptcy negotiations. It was like the Captain of the Titanic telling guests the pork tenderloin was good in the dining hall after he had struck the iceberg.

The trial court granted the defendant's motion for summary judgment. ${ }^{26}$ The court's initial reasoning is somewhat defensible. The market already knew, during the class period, that Loral was in deep financial trouble. ${ }^{27}$ The stock had plummeted to its all-time $\operatorname{low}^{28}$ and its bonds were trading at twenty cents on the dollar. ${ }^{29}$ The plaintiffs were not misled because they knew the truth. The guests on the Titanic saw and heard the collision with the iceberg before considering the pork tenderloin.

One wonders, however, whether an all-time low of $\$ 3.01$ on July $14 \mathrm{th},{ }^{30}$ would not have been $\$ .20$ or so with a prior disclosure of a pending bankruptcy on May 30th. In any event, we will never know, as fact-finding was terminated with a summary judgment motion.

The reasoning gets slippery quickly, however. First, the court noted that the negotiations with Intelsat remained uncertain until the last minute in July. ${ }^{31}$ The parties were resolving difficult issues up until they signed on July 15 th. ${ }^{32}$ This argument would not have worked with the Supreme Court in Basic had there been just an asset agreement and no bankruptcy filing. As I understand the directive in Basic, the May 30th agreement had to be

${ }^{21} I d$. at 522 .

${ }^{22} I d$.

${ }^{23}$ Id. at $522-23$.

${ }^{24}$ See id.

${ }^{25}$ Beleson v. Schwartz, 419 Fed. App'x. 39 (2d Cir. 2011).

${ }^{26} 599$ F. Supp. $2 d$ at 528 .

27419 Fed. App'x. at 40.

28599 F. Supp. 2d at 522

${ }^{29} 419$ Fed. App'x. at 40.

30599 F. Supp. 2d at 522 .

${ }^{31} \mathrm{Id}$. at 526 .

${ }^{32}$ Id. 
disclosed in any major public statement or required public filing made subsequently by Loral. Why does the bankruptcy filing make a difference? Second, and here is the rub, the court said the following:

Such an outcome is further supported by the public policy justifications for allowing a company operating near insolvency to make careful deliberations about its future, free from any obligation to disclose potential bankruptcy. . . Any standard mandating disclosure of contingent bankruptcy planning would put an unacceptable burden on corporations and their officers. Such a standard might amount to a self-fulfilling prophecy, ensuring that all companies that begin contingent preparations for bankruptcy would inevitably go bankrupt because, upon disclosure of the plans, investors would immediately lose confidence in the company and close the capital markets. In some cases, a rule requiring disclosure of bankruptcy plans might prematurely foreclose other options the company may be contemplating that could restore its financial viability and thus avert bankruptcy. ${ }^{33}$

There it is: the previously unstated policy argument behind the technical arguments finding a lack of materiality or a lack of scienter in bankruptcy planning cases. And the argument makes business sense.

But the language does not comport with the language of Basic, in which Justice Blackmun gives the back of his hand to a similar argument for keeping merger discussions quiet until a merger agreement has been signed: "we think that creating an exception to a regulatory scheme founded on a pro-disclosure legislative philosophy, because complying with the regulation might be 'bad for business,' is a role for Congress, not this Court. ${ }^{34}$ In any event, decorum is restored when the Second Circuit, in an unsigned Summary Order affirms the trial court holding only that "[n] otwithstanding the positive business developments reported in the statements upon which plaintiff relies, the market was adequately informed of the dire nature of Loral's financial condition." ${ }^{\text {,35 }}$

It is hard to keep a good reason down, however. In the next and latest case on bankruptcy discussions, Hutchinson v. Perez, another plaintiff class suffered a motion to dismiss. ${ }^{36}$ The plaintiffs alleged that executives of Kodak had made false and misleading statements about Kodak's financial condition in the one-year period leading up to its bankruptcy filing

${ }^{33}$ Id. at 527.

${ }^{34}$ Basic Inc. v. Levinson, 485 U.S. 224, 239 n.17 (1988).

${ }^{35}$ Beleson v. Schwartz, Fed. App'x. 38, 40 (2d Cir. 2011 ).

${ }^{36}$ No. 12 Civ. $1073(\mathrm{HB}), 2012$ WL 5451258, at*1 (S.D.N.Y. Nov. 8, 2012). 
on January $19,2012 .{ }^{37}$ The plaintiffs listed various statements made by the executives during the period that, among other things, trumpeted the company's "digital transformation,"38 anticipated positive results for 2012,39 and assured investors that Kodak had "sufficient financial resources." ${ }^{40}$ Kodak struggled to raise cash. ${ }^{41}$

The company's share price declined to $\$ .78$ a share in late September when Kodak confirmed publicly, less than four months before it filed for bankruptcy, it had hired a law firm known for bankruptcy restructuring and that it had "no intention" of filing for bankruptcy. ${ }^{42}$

The Court held that the plaintiffs had failed to allege scienter and that the statements were not material. The Court based its holding on the failure to allege scienter on the plaintiffs' failure to allege specific contradictory information was available to the defendants at the same time they made their misleading statements. ${ }^{43}$ The Court refused to construe statements contained in the bankruptcy filing detailing the events of the previous year as specific contradictory information. The bankruptcy declaration included an acknowledgment that in September, at the time of the "no intention" statement, Kodak had begun to consider bankruptcy as an option "among others ... . while at the same time it pursued other alternatives to avoid it[.]"44

So if executives are actively engaged in planning a bankruptcy contingency, they can deny it as long as they are pursuing actively and aggressively other options and the markets have multiple warnings of the company's severe financial difficulties. Any claim of scienter is " fraud in hindsight,' [a complaint] filed after a company's bankruptcy based on the conclusory allegation that defendants had or should have been aware of the "liquidity crisis."

To support the argument the judge cited the "public policy justifications" language in the lower court opinion in Beleson v. Schwartz ${ }^{46}$ noted above. The judge also added a footnote citing a quotation from

\footnotetext{
${ }_{38}^{37}$ Id. at *1.

${ }^{38}$ The company, a global giant when camera film dominated photography, was attempting to restructure itself to compete in the digital age. Id.

${ }^{39}$ The CEO notes in an earnings conference call, for example: "[w]e are committed to finish with [sic] this transformation in the year 2012. And our strategy had not changed and we have the resources to execute it[.]" Id. at *2.

${ }^{40} I d$. at $* 1$.

${ }^{41} I d$.

${ }^{42} I d$. at $* 2$.

${ }^{43}$ Id. at *6. The Court put the word "specific" in italics. Id.

${ }^{44} I d$. at $* 5$.

${ }^{45}$ Id. at $* 7$.

${ }^{46}$ Id. at $* 8$.
} 
Professor Pritchard in the Wall Street Journal. ${ }^{47}$ "“Fully informed securities markets aren't the only goal in this world,' said Adam Pritchard, a University of Michigan law professor and former SEC attorney. "If disclosure is destroying businesses, well, how is that good for anyone?',48 Professor Pritchard may be correct on policy but his view does not comport with the language of Basic v. Levinson. Lawyers in Basic argued that early disclosure destroyed acquisition deals that were good for everyone, and they lost. ${ }^{49}$

The court did reach materiality in dicta and "noted" that many of the alleged statements were either forward-looking statements protected by the "safe harbor" provision of the PLSRA ${ }^{50}$ or were not material as "statements of corporate optimism and puffery.",51

\section{THE POLICY}

There can be no doubt that the issue of when a publicly-traded company must disclose its plans to file for bankruptcy is a thorny question. At present, firms appear to have a path to refuse disclosure prior to the filling itself. A firm in distress may hire bankruptcy advisors from investment banks and law firms and discuss bankruptcy plans without disclosing the discussions or plans if the company: discloses specific details of financial distress; documents a continuing effort to pursue alternatives to bankruptcy until the eve of the bankruptcy filing; and makes general positive statements to hold the investors. The company may file for bankruptcy with a simultaneous public announcement and a federal court will grant a summary motion in favor of a company and its officers and against private plaintiffs who held their securities until the filing. ${ }^{52}$

The policy argument is straightforward. Any disclosure of a firm considering a bankruptcy filing will usually doom a struggling firm to file immediately. Investors, customers and suppliers will bolt on the public announcement. The counter-argument, that investors have a right to all material information on all public communications by a firm in distress, seems to have a hollow ring in such circumstances. ${ }^{53}$

\footnotetext{
${ }^{47}$ Id. at *8 n.4 (citing Mike Spector, Keeping Mum about the 'B Word', WaLL ST. J. (Nov. 7, 2012, 7:33 PM), http://online.wsj.com/article/SB10001424127887324073504578105121863526076. html).

${ }^{48}$ Spector, supra note 47.

49 See generally Basic Inc. v. Levinson, 485 U.S. 224 (1988).

${ }^{50} 15$ U.S.C. $\$ 78 \mathrm{u}-5(\mathrm{i})(1)(\mathrm{A})-(\mathrm{B})(2012)$.

${ }_{51}^{51}$ Hutchinson, 2012 WL 5451258, at *8.

${ }_{53}$ Or who held their securities until after the last big price drop before the filing.

${ }^{53}$ For an argument that public disclosure of a potential threat of bankruptcy filing is required in public finance, see Robert A. Fippinger, Securities Law Disclosure
} 
Added to the need to exempt bankruptcy discussion from disclosure is the practical effect of a plaintiff class that survives a motion to dismiss or a motion for summary judgment. The plaintiffs' primary claim is against a company in bankruptcy and any settlement or recovery, if allowed, would come at the expense of other aggrieved investors. The claim is, in essence, a claim by the plaintiffs for an advantage in bankruptcy over where they would otherwise be.$^{54}$ But the Bankruptcy Code protects senior classes of claimants from fraud claims by shareholders. ${ }^{55}$ The protection does not apply to SEC actions under the Fair Funds Provisions of the SarbanesOxley Act of 2002 when the SEC makes distributions to aggrieved shareholders.$^{56}$ It is unlikely, that within the shareholder class of claimants, defrauded shareholders will be able to secure an advantage over other shareholders through private litigation. ${ }^{57}$

Exempting the firm based on a view that such a jump in priority is not merited will still leave the executives who made the offending statements vulnerable. If vulnerable, to protect their personal pocket books, ${ }^{58}$ they will clam up when even a whiff of bankruptcy is in the air and this sudden silence, of course, will be tantamount to a public admission that bankruptcy planning is in the picture. Once again, the silence of once optimistic executives will lead to abandonment by investors, customers and suppliers. The silence, unnatural in the marketing rich atmosphere of the modern business world, will itself force an immediate bankruptcy filing. In a sense, businesses want to protect their need to portray a business as usual front while bankruptcy planning is in the background.

\section{CONCLUSION}

The policy arguments are not novel or unexpected. What is odd, however, is how the federal government reconciles the competing

Requirements for the Political Subdivision Threatened with Bankruptcy, 10 FORDHAM URB. L.J. 541, 594 (1981).

${ }_{54}$ For a discussion of this problem, see Wendy S. Walker et al., At the Crossroads:

The Intersection of the Federal Securities Laws and the Bankruptcy Code, 63 BUS. LAW. 125 (2007).

${ }^{55}$ See 11 U.S.C. $\$ \S 510(\mathrm{~b}), 1129$ (b)(2)(B)(ii) (2012); see also In re Stirling Homex Corp., 579 F.2d 206, 213-14 (2d Cir. 1978), cert. denied, sub nom. Jezarian v. Raichle, 439 U.S. 1074 (1979).

${ }_{56}$ See In re Adelphia Commc'ns. Corp., 327 B.R. 143 (Bankr. S.D.N.Y. 2005), appeal dismissed, sub nom.; see also In re Adelphia Commc'ns. Corp. $222 \mathrm{~F}$. App'x. 7 (2d Cir. 2006), cert. denied, sub nom. Official Comm. of Unsecured Creditors v. Adelphia Commc'ns. Corp., 552 U.S. 941 (2007).

57 The bankruptcy filing generally stays litigation against the debtor. See 11 U.S.C. $\S 362$ (a). Moreover, a claim of fraud is unlikely to augment their claim of loss in the value of their shares against other shareholders.

${ }_{58}$ A claim for indemnification under such circumstances, from an insolvent company, is weak solace. 
arguments by absurdly strict scienter pleading standards and patently false holdings that the bankruptcy discussions are not material to investors. Surely there is a better way, by rule or statute, to create an exemption to our general disclosure rules based on business exigency.

Courts use the same odd reasoning on other types of painful disclosures. When a publicly traded company, particularly a financial company, receives a "Wells Notice" from the Securities and Exchange Commission, ${ }^{59}$ a disclosure of the Wells Notice can threaten the life of the company. In reasoning eerily similar to the bankruptcy discussion cases, courts have held both that failure to disclose a Wells Notice is not a material omission and that such a claim is not an adequate pleading of scienter. ${ }^{60}$ Reasonable investors, if asked, would certainly respond with a wish to have such information for their "deliberations." Courts are using the materiality doctrines and pleading doctrines to delay disclosure of the SEC investigation until the investigation is more certain to result in filed charges. Again, there is merit in the position, but an abuse of the doctrines of materiality and scienter is an odd avenue for government expression of the policy.

Hopefully the time for ad hoc judicial stretching of the basic rules on materiality and pleading to vindicate sensible business concerns in the context of mandatory government disclosure rules will soon collapse on its own weight in a fit of realism. Then the real work can begin and sensible people in Congress and the SEC can debate and reconcile the competing interests of businesses that have valid reasons for disclosing less and investors who want and need a critical quantum of information.

Decision makers could start their investigation by reviewing stock exchanges rules. Stock exchanges around the world have long had rules that parse carefully-crafted exceptions to a general disclosure obligation. ${ }^{61}$

\footnotetext{
${ }^{59}$ The SEC provides a target of an investigation with a Wells Notice whenever the Enforcement Division staff decides, even preliminary, to recommend that the SEC Commissioners bring charges. See generally 17 C.F.R. § 202.5(c) (2013). SEC rules provide the company an opportunity to make a "Wells Submission" to the Commissioners detailing why they should reject the staff's recommendation.

${ }_{61}^{60}$ See Richman v. Goldman Sachs Grp. Inc., 868 F. Supp. 2d 261 (S.D.N.Y. 2012).

${ }^{61}$ The rules are discussed in Oesterle, supra note 5, at $194 \mathrm{nn} .151-54$.
} 
